Barbro Gustafsson är utbildad 4-9 lärare i biologi och kemi med undervisningserfarenhet från år 7-9 i grundskolan. Numera arbetar hon som universitetsadjunkt och lärarutbildare i biologididaktik vid Växjö universitet samt utbildningssamordnare vid lärarutbildningens kansli vid samma lärosäte. Sedan 2003 är hon forskarstuderande i naturvetenskap med utbildningsvetenskaplig inriktning vid Högskolan i Kalmar.

\title{
Naturvetenskaplig undervisning och det dubbla uppdraget
}

\begin{abstract}
The aim of this contribution is to discuss the significance of a democratic approach in science education. Initially, the concept of "democracy" is outlined. According to the deliberative view, democracy is learnt and practiced in communication with others. Furthermore, according to sociocultural theory, communication also enhances scientific content knowledge. This implies that deliberative discussions could be helpful in carrying out teachers' dual assignment: to transmit knowledge and foster independent, judicious, democratic citizens. The discussion is approached through the presentation of a simulated teaching sequence. Based on this scenario, in which a socioscientific issue is the theme for deliberation, the possibilities and limitations of a deliberative approach in science education is discussed.
\end{abstract}

Ofta låser vi oss fast vid en ståndpunkt, av mer eller mindre obskyra skäl, och är oförmögna att vända på perspektivet. Träning i att byta synvinkel ökar inte bara möjligheterna att lösa konflikten utan också vår egen klokskap [...] Människan kan ändra sig, men inte för att någon beordrar henne att göra det, utan för att hon själv bestämmer sig för att hon vill förändras, ibland efter att ha fått inspiration av omgivningen

(Einhorn, 2005, s. 176).

\section{INLEDNING}

Lärarens uppgifter kan sammanfattas i form av ett övergripande uppdrag bestående av två delar: att förmedla ämneskunskaper samt att fostra självständiga och demokratiska samhällsmedborgare. Detta brukar ibland benämnas "det dubbla uppdraget"; kunskapsuppdraget och demokratiuppdraget. Man kan hävda att kunskapsuppdraget $i$ sig är ett demokratiuppdrag, eftersom elever med ämneskunskaper är bättre rustade att klara av sitt praktiska liv och ta aktiv del i demokratiskt beslutsfattande. I svenska skolans styrdokument tydliggörs emellertid att demokratiuppdraget handlar om mycket mer - det handlar om att under demokratiska former och i kommunikativt samspel med andra utveckla ett förhållningssätt i enlighet med samhällets grundläggande värderingar; den så kallade värdegrunden. I läroplanerna föreskrivs vanligtvis inte hur angivna målsättningar skall uppnås, men i detta fall erbjuds viss vägledning beträffande demokratiuppdraget:

Det är inte tillräckligt att i undervisningen förmedla kunskap om grundläggande demokratiska värderingar. Undervisningen skall bedrivas i demokratiska arbetsformer och förbereda eleverna för att aktivt deltaga i samhällslivet. Den skall utveckla deras förmåga att ta ett personligt ansvar. (Regeringen, 1994, avsnitt "Rättigheter och skyldigheter"). 
Av citatet framgår att ämneskunskaper ska utvecklas i en undervisande miljö där läraren på ett medvetet sätt anpassat såväl arbetssätt och innehåll för demokratiuppdraget.

Att i ämnesundervisningen tillgodose såväl kunskapsuppdraget som demokratiuppdraget är inte helt enkelt. Fritzén (2003) menar att undervisningen och därmed didaktikens "Vad-frågor" ofta alltför ensidigt fokuserat på att utveckla ämneskunnandet, medan den demokratiska kompetensen, så som den uttrycks i styrdokumentens övergripande intentioner, reducerats till "Hur-frågor" i bakgrunden av kunskapsuppdraget. Följden blir att motsättningar lätt uppstår, exempelvis genom att demokratiuppdraget upplevs konkurrera utrymmesmässigt med det som bedöms vara viktigare; kunskapsuppdraget. I och med didaktikens uppdelning i allmän- respektive ämnesdidaktik separerades kunskaps- och demokratiuppdraget på ett ännu tydligare sätt. Demokratiuppdraget, som ytterst handlar om gemensam kunskap oavsett ämnesområde, betraktas som en allmändidaktisk fråga, medan kunskapsuppdraget tillhör det ämnesdidaktiska området. Utgångspunkten i föreliggande text är att en sådan uppdelning är olycklig, och att ambitionen istället bör vara att integrera kunskap, lärande och demokrati i den pedagogiska praktiken. Med ett sådant synsätt blir det nödvändigt att göra didaktiska val för att finna integrerande krafter som förenar kunskapsuppdraget och demokratiuppdraget. I texten diskuteras samtalets möjligheter i denna strävan.

Syftet med denna artikel är att tydliggöra förhållandet mellan lärarens ämnesuppdrag och demokratiuppdrag samt utifrån ett undervisningsscenario visa på möjligheter och begränsningar beträffande en samtalsinriktad ansats för att integrera de båda uppgifterna i naturvetenskaplig undervisning. Jag vill inledningsvis lyfta fram demokratibegreppet och hur detta uttrycks och tolkas i svensk skolkontext. Påföljande textavsnitt behandlar samtalet som en teoretisk möjlighet för läraren att hantera det dubbla uppdraget, det vill säga att sörja för såväl naturvetenskaplig ämneskompetens som demokratisk samhällsfostran. Resonemanget handlar om att samtalet dels kan ses som ett demokratiskt mål i sig, dels som en metod för att nå kunskapsmässiga mål inom givet ämnesområde. En didaktisk tillämpning i form av en tänkt undervisningssituation utgör utgångspunkt för den avslutande diskussionen.

\section{DEMOKRATI OCH LÄRANDE}

Hur ska demokratibegreppet förstås? Definitionen är inte helt enkel, eftersom demokrati såväl som frihet och rättvisa är vad man kan kalla "i grunden omstridda begrepp" (Benhabib, 2004; Gallie, 1955), vars innebörder diskuteras och förändras beroende på tid och rum. När man använder begreppet "demokrati" i en text som denna blir det därför viktigt att tydliggöra vilken demokratiuppfattning som avses.

\section{Vad menas med demokrati?}

Demokrati kan diskuteras utifrån olika utgångspunkter. Den amerikanske statsvetaren och demokratiteoretikern Robert A Dahl använder begreppet "upplyst förståelse" för att beskriva vad han anser bör vara en demokratisk målsättning för ett samhälle som eftersträvar politiskt jämställda medborgare. Han menar att upplyst förståelse uppnås "genom en process av upplyst sympati, där vi försöker att fatta andra människors önskningar, behov och värden; och genom ett tankeexperiment där vi försöker föreställa oss vad de skulle välja om de förstod följderna av sina val” (Dahl, 2005, s. 282). Dahl medger att idén om upplyst förståelse är ett ännu så länge ouppnått ideal, men likväl hävdar han att detta tillstånd måste eftersträvas. Han ser det som en "betvingande vision" att politiskt jämställda medborgare har de resurser som krävs för att styra samhället och skapa ett gott liv utifrån huvudprinciper som fred, respekt och allas lika värde. Den upplysta förståelsen bygger på att medborgaren i en demokrati måste förfoga över såväl faktakunskaper som förmågor att sätta sig in i andras situation för att kunna förstå sin omvärld, fatta rätt beslut och klara sig bra i livet. 
En god genomlysning av demokratibegreppet ges Demokratiutredningens forskarvolym (Regeringen, 1999), där bland annat skolans demokratiuppgift behandlas. Statsvetaren Mats Lundström skriver där: "Demokrati är en form av kollektiv maktutövning av jämlika medborgare" (s. 53). Tomas Englund ger i samma skrift en historisk och nutida teckning av demokratibegreppet. Efterkrigstidens funktionalistiska (representativa) demokratiuppfattning, där en minoritet av befolkningen förvaltade de demokratiska värdena i representativ form, har kompketterats med en demokratiuppfattning som innebär ett gemensamt förhållningssätt beträffande exempelvis jämlikhet och resurstilldelning. Här kan två varianter urskiljas:

a) Den ena är den deltagardemokratiska, där utgångspunkten är att den enskilda individen ska erbjudas, och även uppleva, delaktighet och direkt inflytande i den aktuella värdegemenskapen; exempelvis samhället, skolan, bostadsrättsföreningen, föräldrakooperativet. Den politiska målsättningen kan ändå sägas vara att på ett normativt sätt enas om "de rätta värdena" inom värdegemenskapen.

b) Den andra tolkningen är den deliberativa demokratin. Ordet "deliberation" härstammar från latinets "deliberátio", där böjningsformen deli’bero betyder överväga, rådslå, överlägga. En deliberativ demokratiuppfattning tar sin utgångspunkt i betydelsen av möten mellan olika synsätt. Här poängteras samtalets avgörande betydelse för den enskildes demokratiska överväganden, medan deltagardemokratin snarare handlar om individens rätt att välja, och agera i, olika värdegemenskaper (Roth, 2003). Skillnaden dem emellan kan förenklat sägas vara att man enligt den deliberativa demokratiuppfattningen har en uttalad rätt att formulera en avvikande uppfattning, vilket tydliggörs i följande citat:

Det som gör demokrati till demokrati är, vad jag förstår, inte att vi är eniga utan att vi har rätt att vara oeniga och t o m uppmuntras därtill (Liedman, 1986, s. 20).

Bland företrädarna för deliberativ demokrati återfinns Jürgen Habermas, Amy Gutmann, Seyla Benhabib samt, för svenskt vidkommande, Tomas Englund, Klas Roth och Christer Fritzell.

\section{Deliberativ demokrati och deliberativa samtal}

I den deliberativa demokratin är kollektivt beslutsfattande resultat av gemensamma överenskommelser mellan individer som betraktas som moraliska och politiska jämlikar (Benhabib, 2004; Gutmann \& Thompson, 1996). Här har det deliberativa samtalet en avgörande betydelse. Det utgör den grundläggande förutsättningen för beslutsfattandet/ställningstagandet och det måste därför följa vissa principer, som öppenhet, respekt, ömsesidighet och opartiskhet. Fritzell (2003) beskriver deltagarnas rätt att uttrycka sina ståndpunkter på följande vis: "Var och en måste ha rätt att löpande, implicit och explicit, ge sitt ja eller nej till känna, och vara beredda att motivera detta" (s. 33). Denna rättighet åtföljs av skyldigheten att lyssna och ta hänsyn till andras argument. Den mångfald av argument som lyfts fram i samtalet utgör underlaget för den kollektiva beslutsprocessen. Den grundläggande idén om samtalets demokratiska position har dock ifrågasatts, vilket framgår av följande citat:

Dialogue is based, however cautiously it might be considered, in a dominant group fantasy or romance about access to and unity with the other. This is the fantasy of a democracy based in consensus reached from rational debates across different views and groups. It is a truly magnificent, if flawed, romantic ideal (Jones, 2005, s. 62).

I litteraturen och i den pedagogiska kontexten används olika begrepp för liknande typer av samtal; kommunikativa samtal, demokratiska samtal, kvalificerade samtal, diskursiva samtal, participatoriska samtal och deliberativa samtal. Det blir därför viktigt att klargöra att med "deliberativa samtal" avses sådana samtal som präglas av ansvar och moraliskt hänsynstagande, inte bara i förhållande till andra som deltar i samtalet utan även gentemot den eller de som samtalet ytterst berör. Dessa ansvarskrav ställs däremot inte på kommunikativa, diskursiva respektive demokratiska samtal. 
Vilken relation finns då mellan deliberativ demokrati och deliberativa samtal? I den deliberativa demokratin deltar moraliska och politiska jämlikar i deliberativa samtal där målsättningen är att fatta kollektiva överenskommelser i en formell beslutsprocess med samhälleliga implikationer. Det innebär att deliberativ demokrati förutsätter deliberativa samtal, medan det omvända förhållandet (att deliberativa samtal förutsätter deliberativ demokrati) inte nödvändigtvis måste gälla. Man kan alltså föra samtal på deliberativ grund även i sammanhang som präglas av formella och reella auktoritetsskillnader, exempelvis i skolan (Englund, 2006). Med utgångspunkt i företrädare för deliberativ demokrati som Habermas, Benhabib och Gutmann definierar Englund (2004, 2006) vad som bör karakterisera deliberativa samtal i skolan. Han lyfter fram att deltagarna måste eftersträva en kollektivt utformad överenskommelse, om än av temporärt slag. I samtalet, som bör ske utan lärarens närvaro, ska auktoriteter och traditionella uppfattningar kunna ifrågasättas.

\section{Deliberativa samtalets legitimitet i skolan}

I Sverige har det deliberativa synsättet haft betydelse för innehållet i skolans nu gällande styrdokument: skollagen, läroplanerna och kursplanerna. Skolverket har exempelvis tagit initiativ till en rapport om deliberativa samtal i skolan, skriven av Englund (2001). I förordet skriver representanter från Skolverket att sådana samtal betraktas som demokratins bärande element. De bör därför ges utrymme i skolans arbete för att utveckla elevers demokratiska kompetens, beskriven som individens förmåga att agera utifrån grundläggande demokratiska värderingar samt förmåga att ta ställning i olika frågor. För att kunna fatta välgrundade beslut krävs dessutom att man utvecklar förmåga att även sätta sig in i andras ställningstaganden. I sådana processer får kommunikationen/samtalet stor betydelse.

Samtalet, med deliberativa förtecken, fokuseras även i en publikation om värdegrunden (Skolverket, 2003). Här poängteras att samtalet ses som skolans viktigaste demokratiska redskap, och att skolan "kan ge demokratin ett innehåll" genom ett kommunikativt arbetssätt där man "utgår från människors olikheter och samtalar om dem" (s. 27).

Forskning kring deliberativa samtal i språkundervisningen har presenterats av Tornberg (2007) och Molloy (2003). Tornberg visar att i skolan "ägs" språket i alltför hög utsträckning av läraren och läromedlen. Hon menar att språkklassrummet måste få utgöra en demokratisk arena där elever ges utrymme att utbyta tankar och åsikter kring frågor som de kan uppleva som angelägna och intressanta. Molloy anser att skolan inte tillräckligt väl utnyttjar sin potential som demokratisk mötesplats och social institution. Hon har i sin forskning visat att tonåringar vill diskutera demokrati- och moralfrågor, medan lärarna gärna undviker sådana diskussioner.

Ovanstående avsnitt har behandlat samtalets roll för att utveckla demokratiska kompetenser hos deltagarna. Med stöd i uppfattningen att samtal främjar lärande finns skäl att anta att även ämnesspecifik kompetens kan utvecklas genom samtal. Den kunskapsteoretiska utgångspunkten är att lärande inte är ett individuellt projekt, utan allt lärande sker och medieras i en social och kulturell kontext.

\section{Samtal och lärande ur ett sociokulturellt perspektiv}

Den ryske psykologen Lev Vygotskijs (1896-1934) tankar kring vad som kom att kallas den sociokulturella synen på lärande har fått stor genomslagskraft i vårt utbildnings- och undervisningssystem. Enligt Vygotskij är tänkande och språk förknippade, om än inte identiska, med varandra. Tänkandet fortlöper i språket. Vygostkij menade att tänkande kan ses som ett inre språk, medan tal, kommunikation med andra, kan ses som ett yttre språk. Båda är nödvändiga för lärandet. Enligt det sociokulturella perspektivet utvecklas kunskaper och lärande sker när man ges tillfälle att uttrycka sina egna tankar inför andra. I och med att ordens betydelse utvecklas i den sociala kommunikationen så utvecklas även tänkandet, eller med Vygotskijs ord: "[...]tankens relation till ordet är en levande process där tanken föds i ordet” (Vygotskij, 1934/2005, s. 472). Genom att 
i undervisningen erbjuda goda förutsättningar för kommunikation med andra skapas även goda förutsättningar för lärande och kunskapsbildning.

Bland de skandinaviska företrädarna för det sociokulturella perspektivet återfinns Roger Säljö och Olga Dysthe. Säljö (2000) menar att: "det är just i interaktion mellan människor som kunskaper och färdigheter får liv. Möjligtvis är det den enda tes som håller oavsett vilka redskap människan utvecklar" (s. 250).

Skolans styrdokument speglar samhällets syn på lärande och kunskap. En väsentlig ståndpunkt är att i skolan ska eleverna formas till fria och självständiga individer som kan, vill och vågar argumentera och ta ställning för att förändra. Undervisningen ska med andra ord vara frigörande i betydelsen att rådande sociala och kulturella villkor och föreställningar ska kunna ifrågasättas. I den meningen har styrdokumenten och även argumentationen i denna artikel influerats av det som Habermas (1978) benämner ett emancipatoriskt kunskapsintresse.

Mot bakgrund av läroplanens övergripande intentioner beträffande skolans demokratiuppdrag och den sociokulturella synen på lärande ska vi nu se hur demokratiuppdraget återspeglas i de mer detaljerade styrdokumenten för svensk skola; kursplanerna och betygskriterierna för de naturvetenskapliga ämnena.

\section{NATURVETENSKAPLIG UNDERVISNING OCH DEMOKRATIUPPDRAGET}

För den svenska grundskolans del (som får utgöra den avgränsade delen av skolan i denna text) behandlas de naturvetenskapliga ämnena dels gemensamt under rubriken "Naturorienterande ämnen", dels uppdelat ämnesmässigt i biologi, fysik och kemi. Demokratiuppdraget, som utgör en väsentlig del av det vi kallar värdegrundsperspektivet, betonas på flera håll i den sammanfattande texten kring de naturorienterande ämnena. Här framgår att utbildningen i naturvetenskapliga ämnen bland annat syftar till: "ett förhållningssätt till kunskaps- och åsiktsbildning som står i samklang med naturvetenskapens och demokratins gemensamma ideal om öppenhet, respekt för systematiska undersökningar och välgrundade argument" (Skolverket, 2000, s. 46). Ett annat viktigt syfte med utbildningen är att träna ett kritiskt och konstruktivt förhållningssätt i argumentation med naturvetenskapligt innehåll samt tillämpa demokratiska färdigheter som "lyhördhet och respekt för andras resonemang och ställningstaganden" (s. 48). Diskussionerna kring människa och natur ska omfatta "ett brett spektrum av argument, t.ex. etiska, estetiska, kulturella och ekonomiska" (s. 48).

Av detta framgår att demokratiska färdigheter som öppenhet, respekt för andras resonemang och förmåga att göra värderande ställningstaganden i tvärvetenskapliga diskussioner skall tränas inom naturvetenskaplig undervisning. Här återfinns en samsyn mellan den övergripande läroplanstexten som anger målsättningen för all utbildning och kursplanetexten för de naturorienterande ämnena.

Nästa nivå utgörs av betygskriterierna. Bland de gemensamma kunskapsmål som ska vara uppnådda i slutet av nionde skolåret återfinns att eleven skall "ha insikt om skillnaden mellan naturvetenskapliga påståenden och värderande ståndpunkter", samt "kunna använda sina kunskaper om naturen, människan och hennes verksamhet som argument för ståndpunkter i frågor om miljö, hälsa och samlevnad". Eleven skall även "kunna exemplifiera hur naturvetenskapen kan användas för att skapa bättre livsvillkor men också hur den kan missbrukas" och "ha inblick i konsekvenserna av olika etiska ställningstaganden i miljöfrågor" (Skolverket, 2000, s. 50).

I dessa kunskapsmål återspeglas åtminstone delar av de gemensamma, övergripande strävansmål som redovisats ovan. Hur ser det sedan ut i kunskapsmål och betygskriterier för de enskilda naturvetenskapliga ämnena? En sammanfattande slutsats är att eleven, för att få betyget "Godkänd", 
ska kunna använda sina kunskaper i diskussioner inom valda områden (här nämns biologisk mångfald, sexualitet, hälsa och motion och resursanvändning). Det är däremot svårt att finna stöd i angivna betygskriterier för att de önskade demokratiska kvalitéerna "öppenhet och respekt för systematiska undersökningar och välgrundade argument" samt "lyhördhet och respekt för andras resonemang och ställningstaganden" verkligen ska bedömas/betygsättas. Bedömningskriterierna fokuserar istället på den individuella förmågan att granska och värdera ställningstaganden, vilket i synnerhet framgår av de kriterier som gäller för högre betyg i naturvetenskapliga ämnen. De demokratiska intentioner och argument som lyfts fram i den övergripande texten kan därför sägas vara åtminstone delvis åtskilda från den naturvetenskapliga kompetens som ska bedömas enligt betygskriterierna. I dessa sätts det individuella "görandet" i fokus, medan huvuddelen av de mer kommunikativa och processinriktade demokratiska kompetenser som lyfts fram i de övergripande demokratimålen tycks hamna i skymundan. I sin avhandling skriver Carlsson (2006) att de olika delarna av skolans styrdokument tycks vara formulerade utifrån helt olika rationaliteter, vilket medför att demokratiuppdraget får svårt att nå ända fram till "klassrummets konkreta verklighet" (s. 83).

När det gäller måluppfyllelsen för kunskapsuppdraget erbjuds etablerade metoder och mätinstrument i form av kunskapstester som jämför och rangordnar ämnesmässiga kunskaper såväl lokalt/ individuellt som internationellt. Däremot råder det brist på verktyg och tydliga kriterier för att utvärdera hur väl de lärande inom den naturvetenskapliga undervisningen utvecklat den demokratiska kompetensen i form av ett socialt förhållningssätt. Att, som exempelvis biologilärare, ha till uppgift att bidra till elevens demokratiska utveckling kan då upplevas som både ansvarsfullt och svårt, i synnerhet mot bakgrund av den relativa otydlighet som omger demokratiuppdraget i förhållande till kunskapsuppdraget. Enligt ovanstående resonemang skulle samtalsbaserad undervisning kunna erbjuda möjligheter att integrera demokratiuppdraget och kunskapsuppdraget. Jag vill utifrån en hypotetisk undervisningssituation problematisera detta, men låt oss först fördjupa oss något i diskussionen kring samtal och demokratisk kompetens inom naturvetenskaplig utbildning.

\section{Att samtala för naturvetenskaplig kunskapsbildning och demokratisk kompetens}

Flera forskare har tidigare belyst samtalets/argumentationens roll för den naturvetenskapliga kunskapsbildningen. Det huvudsakliga motivet för att samtala i och kring naturvetenskap har i dessa fall varit att utveckla naturvetenskapliga kunskaper och socialiseras i den naturvetenskapliga kulturen (se exempelvis Benckert, Pettersson, Aasa, Johansson \& Norman, 2005; Driver, Newton \& Osborne, 2000; Osborne, Erduran \& Simon 2004; Ritchie, 2001; Solomon, 1991; Sutton, 1992). I takt med ett sjunkande intresse för naturvetenskaplig utbildning har politiska och utbildningsvetenskapliga satsningar gjorts för att tydliggöra den samhälleliga och individuella nyttan med naturvetenskaplig bildning. Bland exemplen kan nämnas det särskilda EU-projektet "Science and Society" samt internationella satsningar kring "Scientific Literacy" och "Science, Technology and Society" (STS).

En övergripande tolkning är att dessa satsningar eftersträvar att utifrån verklighetsanknutna situationer och engagerande experiment åstadkomma förståelse och känsla för såväl naturvetenskapens natur och fenomen som dess historiska och nutida roll i samhället. Tydlig koppling mellan naturvetenskaplig bildning och demokratisk kompetens återfinns dock sällan i den vetenskapliga dokumentationen. Vid sökning i ERIC (se www.eric.ed.gov/), världens största referensdatabas för vetenskaplig litteratur inom det utbildningsvetenskapliga fältet, återfanns 217 referenser med "Scientific Literacy" i titelfältet, medan endast två av dem behandlade demokratiaspekten. Sökorden var: "scientific"(ti) AND "literacy" (ti) AND "democra*"(anywhere). Motsvarande sökning beträffande "Science Education" gav 4758 träffar, varav 47 av dem innehöll demokratiska argument. Sökord: "science"(ti) AND "education"(ti) AND "democra*"(anywhere). Motsvarande sökning med sökorden "social" (ti) AND "education" (ti) AND "democra*" (anywhere) gav 173 referenser. 
Samtliga sökningar genomfördes 2007-01-08. Resultatet antyder att hittills har relativt få ägnat sig åt att studera demokratiperspektivet i naturvetenskaplig undervisning. Ett begrepp som jag funnit bland det fåtal referenser som behandlar naturvetenskap och demokrati är "Civic Science". Begreppet omfattar olika demokratiska ambitioner. Dels den klassiska; att öka medborgarnas kunskaper och förståelse av naturvetenskap och därigenom stärka deras demokratiska kompetens. En annan typ av demokratisk strävan i konceptet "Civic Science" är att stärka och stimulera delaktighet och representation för att främja demokratisering av naturvetenskapen. (Bäckstrand, 2003; Clark \& Illman, 2001).

Man kan även notera att två artiklar på temat naturvetenskap och demokrati nyligen publicerats i NorDiNa (Kolstø, 2006; Paulsen, 2006). Kolstø menar att den naturvetenskapliga undervisningen måste förändras. Det gamla, traditionella undervisningsinnehållet, så som det presenteras i läromedlen, utgörs av "ready-made-science" som svarar på frågor som ingen elev har ställt (Kolstø, 2001, 2006). Han är en av dem som hävdar att elever kan lära sig argumentera och fatta beslut genom att i den naturvetenskapliga undervisningen diskutera kontroversiella och aktuella frågor som innefattar såväl naturvetenskap som sociologiska aspekter ("socioscientific issues") (Kolstø, 2001). Han har arbetat med en undervisningsmodell som han kallar "consensus conference model" där exempelvis former som rollspel och paneldebatter förekommer (Kolstø, 2000). Den uttalade ambitionen är att uppnå såväl kunskapsmål som demokratimål genom de diskussionsinriktade inslagen. Här återfinns de karaktärsdrag som präglar deliberativ demokrati och deliberativa samtal. Även Paulsen (2006) påtalar behovet av en förändrad naturvetenskaplig undervisning för att kunna uppnå läroplanens målsättning att eleverna ska utveckla en kritisk demokratisk beredskap så att de kan agera självständigt, kritiskt och reflekterat. Han kritiserar den traditionella naturvetenskapliga diskursen där alltför mycket vikt läggs på begreppsmässig precision och för lite på tvärvetenskapligt, "mjukt" innehåll. Han lyfter särskilt fram "klassedialogen" (av deliberativt slag) där verklighetsnära, autentiska och kontroversiella ämnen diskuteras. Jag vill nu ge ett exempel på hur en sådan undervisningssituation skulle kunna te sig.

\section{ETT UNDERVISNINGSSCENARIO MED DELIBERATIVA FÖRTECKEN}

Detta avsnitt behandlar en fingerad undervisningssekvens i biologiämnet för elever i grundskolans år 9. Den tänkta klassen består av en representativ grupp elever, vilket bland annat innebär att några är mer studiemotiverade än andra och vissa är påfallande tysta och tillbakadragna under lektionerna.

\section{Didaktiska överväganden}

Undervisningen ska i detta fall handla om genetik och genteknik. Läraren har i planeringsarbetet besvarat de didaktiska frågorna om legitimitet och stoff genom att utgå från styrdokumentens direktiv och riktlinjer beträffande såväl demokratiuppdraget som kunskapsuppdraget. Beträffande kunskapsmålen i genetik och genteknik anges i kursplanen för biologiämnet (Skolverket, 2000) att eleven i slutet av år 9 skall "ha kännedom om det genetiska arvet" (s. 53). samt "kunna använda såväl naturvetenskapliga som estetiska och etiska argument i frågor om [...]användning av genteknik" (s. 54). Läraren önskar även att eleverna ska träna färdigheter för att nå det kunskapsmål som handlar om att skilja på "naturvetenskapliga påståenden och värderande ståndpunkter" (s. 50). De två sistnämnda kan betraktas som tydligt uttryckta demokratimål.

Den uttalade målsättningen är att erbjuda en undervisningssituation som tränar och utvecklar såväl demokratiska färdigheter som ämnesmässiga kunskaper i genetik och genteknik. Läraren, som inspirerats av deliberationens ideologi, vill att elevernas samtal ska utgöra ett centralt moment. Lärarens strävan är att samtalsunderlaget ska appellera till ungdomars livsvärld och stimulera till diskussion då det inte med nuvarande kunskaper går att enkelt avgöra vad som är rätt eller fel i den problematik som presenteras. Kunskaper om genetik och genteknik behövs för att kunna delta 
i samtalet, men den öppna problematiken med svårbedömda samhälleliga implikationer (exempelvis i form av miljö- och hälsoeffekter) gör att naturvetenskapliga ämneskunskaper inte erbjuder tillräcklig grund för elevernas ställningstagande. Samtalsämnet får härigenom karaktären av en "socioscientific issue". (Kolstø, 2001; Ratcliffe \& Grace, 2003; Sadler \& Donnelly, 2006). Läraren i vårt undervisningsscenario kan välja att antingen konstruera ett eget samtalsunderlag med en problematik som uppfyller karaktären hos en "socioscientific issue". En fördel med detta alternativ är att läraren kan presentera ett tillrättalagt innehåll med önskad grad av komplexitet. Det andra tillvägagångssättet är att använda en autentisk händelse eller situation, exempelvis något som beskrivits i massmedia. I detta exempel väljer läraren det senare alternativet. Förhoppningen är att eleverna ska kunna känna att ämnet är viktigt att diskutera eftersom det är verklighetsförankrat och "på riktigt".

\section{Samtalsunderlaget}

Läraren väljer följande notis från dagstidningen "Dagens Nyheter" (2006-08-12):

\section{GMO-framställt fiskprotein i glasstruten}

Fett- och sockerdebatten har nu nått våra glassar. Unilever, som äger GBglace, hoppas kunna få fram en magrare glass genom att använda ett protein från arktiska fiskar. Proteinet gör att kristallisering sker vid lägre temperaturer än normalt. För fiskarna innebär det att de inte stelnar, för glassen att den är smidig trots mindre fett. Företaget har nu lämnat in en ansökan i Storbritannien om att få använda proteinet inom EU. Men det lär vålla debatt eftersom fiskproteinet inte räcker till utan måste mångfaldigas med jästorganismer och genmodifiering i framställningsprocessen. Blir det strid runt storstruten?.

@ DAGENS NYHETER. Notisen används i denna artikel med tillstånd från upphovsrättsinnehavaren.

Bedömningen är att tidningsnotisen om glass som innehåller GMO-framställt protein med härstamning från fisk har karaktären av en "socioscientific issue". Den har ett naturvetenskapligt innehåll som handlar om genetik och genteknik. Samtidigt inbjuder den till värdebaserade diskussioner kring hälsoaspekter och GM-livsmedel. Även företagsetiska aspekter kan bli föremål för diskussion, eftersom intentionen att producera en bättre och magrare produkt kombineras med tänkbara risker att inducera sjukdomsreaktioner hos glassätare med fiskallergi. Det senare framgår dock inte av notistexten.

\section{Elevernas förberedelser}

Lärarens bedömer att eleverna för att kunna samtala kring denna notis behöver naturvetenskapliga kunskaper om dels vad en gen är samt förhållandet mellan gen och protein, dels genteknik med historiska och moderna exempel (inklusive GM-livsmedel och transgena organismer). Läraren inleder därför undervisningssekvensen med en lektionsserie. Stoffet består av naturvetenskaplig fakta i form av läromedelsbaserad "ready-made-science" (Latour, 1987), men även inslag från den allmänna debatt som speglar osäkerheten kring de nya framstegen med genteknik. Eleverna får till uppgift att studera inläsningslitteratur inför samtalsuppgiften. Det anvisade studiematerialet ligger även till grund för delar av den examination som sker i slutet av undervisningssekvensen. 


\section{Samtalsuppgiften}

Läraren presenterar nu tidningsnotisen. För att eleverna ska känna att de har något att bidra med i diskussionen redan från början och för att de ska kunna se och reflektera över sitt eget lärande under processens gång önskar läraren att eleverna börjar med att enskilt och skriftligt formulera argument för respektive mot denna glass. Dessa samlas in för att åter delas ut vid utvärderingstillfället. Läraren har på förhand delat in eleverna i såväl arbetsgrupper som tvärgrupper. Grupperingarna består av 4-6 personer. Läraren beskriver hur övningen har lagts upp, och varje elev får såväl notistexten som följande uppgiftsbeskrivning:

\section{Skulle du köpa glassen?}

Syftet med denna övning är att du ska utveckla kunskaper och färdigheter såväl i genetik och genteknik som i demokratiskt förhållningssätt. Med utgångspunkt i tidningsnotisen om glassen kommer du att fördjupa dig i frågeställningar som inte alltid är så lätta att besvara, åtminstone inte utifrån kriterier som "rätt" eller "fel". Under gruppsamtalen kommer du att få tillfälle att samla och värdera argument för att vid examinationstillfället kunna föra en utvecklad argumentation för ditt eget ställningstagande - skulle du köpa glassen?

Kom ihåg att det är viktigt att du lyssnar noga på vad andra har att säga och låter alla komma till tals under samtalen.

Hela uppgiften består av fyra delar, där den första och den sista ska lösas enskilt av dig. Del 2 och del 3 löser du tillsammans med dina klasskamrater. Den sista deluppgiften löser du i samband med examinationen.

Del 1

Din första uppgift är att på egen hand hitta så många argument som möjligt, både för och mot denna glass. Skriv ner argumenten på papper som lämnas till din lärare. Denna uppgift löser du alltså enskilt.

\section{Del 2}

Du ska nu diskutera glassfrågan med andra i din arbetsgrupp. Er uppgift går inte ut på att ni skall komma till ett gemensamt beslut i glassfrågan. Istället handlar det nu om att gemensamt ta fram så många argument som möjligt. Försök ta hänsyn till alla som kan påverkas av en lansering av glassen. Ställ frågor om det är något i notisen som du inte förstår. Du personligen ansvarar för att du får med dig samtliga argument, nedskrivna på papper, till tvärgruppen i del 3.

Del 3

Varje tvärgrupp består av representanter från de olika arbetsgrupperna. Tvärgruppens uppgift är att ta del av hur man har resonerat i de olika arbetsgrupperna. Din uppgift i tvärgruppen är att redogöra för de argument som ni har diskuterat i arbetsgruppen. Det är mycket viktigt att tvärgruppens medlemmar ser till så att alla får komma till tals i tur och ordning. Lyssna noga på varandra och ta del av varandras argument! Försök att utveckla argumenten för de olika alternativa ställningstagandena. Huvuduppgiften är inte att till varje pris uppnå en gemensam hållning i glassfrågan. Kanske är ni inte alls överens? Försök då att plocka fram några delar i resonemanget som ni kan enas kring. Tvärgruppen redovisar sitt arbete i slutet av lektionen.

\section{Del 4}

Genom arbetet i de olika grupperna bör du ha fått ta del av flera alternativa strategier med tillhörande argument. Vid examinationen ska du ta slutlig ställning och argumentera för ditt ställningstagande - skulle du köpa glassen? 


\section{Examination}

Undervisningssekvensen avslutas med en skriftlig examination som avser att pröva såväl naturvetenskapliga ämneskunskaper som demokratisk kompetens enligt gällande kunskapsmål för år 9 (Skolverket, 2000). Förutom mer kvantitativt inriktade frågor kring genetik och genteknik vill läraren därför att eleven även ska utveckla en argumentation kring glassexemplet, och då tydliggöra vilka argument som kan klassas som argument förankrade i naturvetenskaplig kunskap och vilka som kan betraktas som värdebetonade (a.a. s. 50). Några svar kommer att kunna bedömas utifrån kriterier av "rätt" eller "fel", medan kvalitéer i naturvetenskaplig och etisk argumentation blir avgörande för glassuppgiften. Kvalitéerna i det etiska resonemanget bedöms utifrån elevens förmåga att söka en lösning som inte enbart begränsas till det egna intresset utan involverar de som ytterst berörs vid en lansering av glassen (jfr Gerrevall, 2003).

\section{Elevernas utvärdering}

Läraren är angelägen om att få elevernas synpunkter på denna undervisningssekvens. Därför får eleverna göra en skriftlig utvärdering i nära anslutning till examinationstillfället. Elevernas inledande argumentering i glassfrågan delas åter ut. I en av utvärderingsfrågorna får eleven till uppgift att föra ett resonemang kring huruvida de egna argumenten förändrades genom samtalen och i så fall hur. Andra frågeställningar avser att belysa hur samtalen fungerade; Fick alla komma tals? Bemöttes åsikter respektfullt? Hur bidrog du i samtalen? Fanns oenighet i gruppen, och hur hanterades i så fall denna? Har du förslag på hur övningen skulle kunna förbättras? Läraren vill att utvärderingen ska bli vägledande för elevernas självreflektion och kommande samtalsuppgifter och presenterar därför en sammanfattning av utvärderingen för diskussion med klassen.

\section{Utmaningar}

Lärarens utvärdering efter genomförd övning handlar bland annat om i vilken utsträckning samtalen uppfyllt deliberativa samtalets kriterier. Kan man till exempel hävda att eleverna verkligen kommit överens om samtalsreglerna, eller är det snarare så att läraren förmedlat dessa som direktiv? Och i vilken utsträckning har eleverna hållit sig till dem? Läraren konstaterar att elevernas utvärdering endast till en del besvarar de båda frågorna.

En annan tveksamhet gäller det deliberativa samtalets strävan efter gemensam slutlig överenskommelse, vilken gör att några röster kan tvingas till tystnad. Därför har läraren i samtalsuppgiften valt att be tvärgrupperna presentera något som gruppmedlemmarna kan anse sig vara överens om istället för att efterfråga en gemensam hållning i glassexemplet.

I enlighet med det deliberativa samtalets ideal (Englund, 2004, 2006) har läraren hållit en låg profil genom att vara tillgänglig för frågor men inte gå runt bland grupperna under samtalsprocessen. Motivet för den passiva hållningen är att en intervention av läraren skulle störa samtalen och frånta eleverna ansvaret för samtalsprocessen. Läraren ser dock en problematik i att sakna möjligheter att bedöma hur samtalen fortlöper och hur enskilda elever argumenterar.

Lärarens funderar även på hur de tystlåtna elevernas rättigheter förvaltas i samtalen. Ett grundläggande krav i en deliberativ demokrati är att alla ska få göra sin röst hörd och alla ska behandlas respektfullt. Innebär detta då att alla måste tala, eller kan tysta elever göra anspråk på en demokratisk rättighet att få vara tysta?

\section{Diskussion}

Samtalet har fått stort utrymme i denna text. Kommunikation i form av samtal med andra gynnar individuellt lärande enligt sociokulturell teori. Dessutom är samtalet nödvändigt för demokratiskt beslutsfattande enligt den deliberativa demokratiuppfattningen. Samtal erbjuder därför möjligheter att integrera det givna kunskaps- och demokratiuppdraget. Den fingerade undervisningssituatio- 
nen visar samtidigt att samtalsbaserad undervisning inte är okomplicerad. Det deliberativa samtal som efterstävas i undervisningsexemplet är en förhållandevis styrd procedur, vilket kan uppfattas som tveksamt utifrån demokratiska frihetsanspråk. Deltagarna måste exempelvis komma överens om vilka samtalsregler som ska gälla och att de ska även kunna vara överens om att följa dem. Hit hör att de måste visa respekt, tolerans och lyhördhet för varandra och för andras argument. De som deltar i ett deliberativt samtal ska avslutningsvis kunna presentera en gemensam hållning, även om det kan vara frågan om en temporär överenskommelse. Denna konsensusinriktade strävan har mött kritik, då man menar att en uttalad strävan efter att komma överens i ett samtal kan motverka en kritisk argumentation och därigenom hämma diskussionen. En annan synpunkt är att ofrånkomliga maktstrukturer mellan olika elever såväl som mellan lärare och elev omöjliggör äkta deliberativa samtal. Likaså har lärarens relativt undanskymda roll i deliberativa samtal ifrågasatts.

Ett bekymmer för läraren i vårt exempel är hur de tysta elevernas synpunkter kommer till uttryck i samtalen. En liknande problematik gäller elever med språkliga svårigheter eftersom just talet starkt favoriseras i sammanhanget. Att kringgå problemen genom att inte samtala är sannolikt inte ett bättre alternativ. I en antologi som behandlar demokratiska samtal i undervisningen (Boler, 2005) hävdar en av författarna att lärare måste frångå idén om talet som den överlägsna kommunikationsformen och eftersträva vad hon beskriver som "en pedagogisk förståelse av tystnaden". Läraren har därför skyldighet att inte till varje pris "tysta tystnaden" genom att tvinga alla att yttra sig. Här framgår även att man bör vara medveten om att tystnad inte alltid ska tolkas som en resignation inför andras argument. Ibland är tystnaden ett medvetet motstånd mot detsamma (a.a.). Det skulle innebära att lärare som har ambitionen att få till stånd deliberativa samtal där alla kommer till tals istället bör inrikta sig på att samtalet ska vara av sådan karaktär att även tysta elever upplever frihet att yttra sig och trygghet i vetskapen om att bli respektfullt bemött. Läraren måste därför på ett didaktiskt medvetet sätt kontinuerligt arbeta för ett arbetsklimat som minskar riskerna för att starka röster avfärdar eller tillintetgör andras argumentering. I undervisningsscenariot väljer läraren, som har god kunskap om sina elever, att på förhand fatta beslut om gruppindelningen. Motivet är att undvika gruppkonstellationer med påtagliga maktasymmetrier. En annan åtgärd är tydliggöra och söka överenskommelse kring samtalsreglerna. Av exemplet framgår samtidigt svårigheterna med att försäkra sig om att eleverna är överens om att följa samtalsreglerna. Även om läraren i informerar eleverna om riktlinjerna för samtalen och ber dem följa dessa så är det inte säkert att de anser sig ha kommit överens om dem. Ett underskrivet samtalskontrakt skulle eventuellt minska osäkerheten kring denna fråga.

I undervisningsscenariot håller läraren en medvetet låg profil i samtalen. Här förtydligar Englund (2006) att läraren absolut inte ska abdikera från den reella (kunskapsmässiga) och formella auktoriteten. I undervisningssituationer med deliberativa samtal kvarstår traditionella uppgifter som att planera och leda arbetet och besvara ställda frågor. Genom valet av stoff och arbetssätt kan läraren tillsammans med eleverna skapa förutsättningar för en "diskursiv situation", där man gemensamt kommit överens om riktlinjerna beträffande ömsesidig respekt och strävan efter förståelse (a.a.). I exemplet väljer läraren att via examinations- och utvärderingsfrågorna fästa uppmärksamhet på hur väl eleverna förvaltat ansvaret för samtalsprocessen.

Beträffande valet av samtalsämne föreslås här autentiska eller fingerade "socioscientific issues". Dessa är frågeställningar där problematiken innefattar ett naturvetenskapligt faktainnehåll såväl som sociologiska (normativa) och subjektiva värdeaspekter. Det handlar inte om att låta eleverna diskutera ifall tyngdlagen existerar eller inte, utan istället krävs ett verklighetsnära exempel där tyngdlagen ingår som en naturvetenskaplig faktadel i förhållande till de andra två aspekterna som angivits ovan. Diskussionerna kan exempelvis handla om genmodifierade livsmedel, kraftledningsdragningar, kärnkraft, etanolbilar, stamcellsforskning, fosterdiagnostik, torskfisket i Östersjön eller kemiska bekämpningsmedel; ämnen som förhoppningsvis upplevs som relevanta och verklighetsnära för eleverna. Ett stort antal tänkbara samtalsämnen återfinns eller kan konstru- 
eras inom undervisningsområdet "Hållbar utveckling". Liksom i exemplet med glassen i undervisningsscenariot så erbjuds flera uppslag till samtalsämnen bland notiserna i massmedia.

\section{Implikationer för lärarutbildningen}

Vilken relevans har då denna diskussion för lärarutbildningens del? I den svenska examensordningen för lärare anges att den som examineras efter fullföljda studier bland annat ska kunna: "förmedla och förankra samhällets och demokratins värdegrund" . Det innebär att lärarstudenterna under sin utbildning måste träna sin förmåga att göra just detta. För blivande lärare i biologi, fysik och kemi måste värdegrunds- och demokratiaspekterna integreras i den så kallade ämnesdidaktiska delen av utbildningen. Ett sätt att närma sig värdegrundsaspekterna i ämneslärarutbildningen skulle kunna vara att låta lärarstudenterna planera, genomföra och utvärdera samtal av liknande slag som i undervisningsscenariot.

\section{Slutord}

Avsikten med argumentationen har varit att fästa uppmärksamhet på att samtal av deliberativ karaktär kan erbjuda teoretiska möjligheter att förena lärarens dubbla uppdrag i den naturvetenskapliga undervisningen. Resonemanget har även belyst begränsningar hos det deliberativa samtalet. Detta ger utrymme för viss frihet att göra avsteg från någon delaspekt av det deliberativa samtalets ideal för att i undervisningssituationen pröva idén om dess potential. Den stora och grannlaga uppgiften att bedöma och utvärdera ifall sådana samtal kring "socioscientific issues" verkligen bidrar till såväl ökad demokratisk kompetens och fördjupade kunskaper i naturvetenskap återstår att behandla empiriskt. Här skulle en undersökning baserad på det presenterade undervisningsscenariot kunna ge vägledning.

Avslutningsvis vill jag återknyta till textens inledande citat. Einhorn menar att när vi låst oss fast vid en ståndpunkt kan vi behöva inspiration från andra för att kunna ändra vårt ställningstagande. Träning i att byta perspektiv ökar vår "klokskap". Citatet har valts ut av två skäl. För det första - mot bakgrund av såväl kunskaps- som demokratiteoretiska utgångspunkter, indikeras i citatet samtalets möjligheter beträffande perspektivbyte, hänsynstagande och nytt lärande. För det andra - om elever och blivande lärare under sin utbildning ges möjlighet att träna argumentationsförmåga, eget ställningstagande och demokratisk utveckling genom samtal kring komplexa frågor med naturvetenskapligt innehåll skapas möjligheter för perspektivbyten med sikte på en pedagogisk diskurs i naturvetenskaplig undervisning med målsättning att förena det dubbla uppdraget; ämneskunnande och demokratisk kompetens. 


\section{REFERENSER}

Benckert, S., Pettersson, S., Aasa, S., Johansson, O. \& Norman, R. (2005). Gruppdiskussioner runt kontextrika problem i fysik - Hur ska problemen utformas? NorDiNa, 2, 36-45.

Benhabib, S. (2004). Jämlikhet och mångfald: demokrati och medborgarskap i en global tidsålder. Göteborg: Daidalos.

Boler, M. (2005). Democratic Dialogue in education - Troubling speech, disturbing silence. New York: Peter Lang Publishing Inc.

Bäckstrand, K. (2003). Civic Science for Sustainability: Reframing the Role of Experts, PolicyMakers and Citizens in Environmental Governance. Global Environmental Politics, 3(4), 24-41.

Carlsson, L. (2006). Medborgarskap som demokratins praktiska uttryck i skolan - diskursiva konstruktioner av gymnasieskolans elever som medborgare. Växjö: Växjö University Press.

Clark, F. \& Illman, D. L. (2001). Dimensions of Civic Science. Science Communication, 23(1), 5-27.

Dahl, R. A. (2005). Demokratin och dess antagonister. Stockholm: Ordfront.

Driver, R., Newton, P. \& Osborne, J. (2000). Establishing the Norms of Scientific Argumentation in Classrooms. Science Education, 84, 287-312.

Einhorn, S. (2005). Konsten att vara snäll. Stockholm: Forum.

Englund, T. (2001). Deliberativa samtal som värdegrund - historiska perspektiv och aktuella förutsättningar. Hämtad 28 feb. 2007 från Skolverkets hemsida. Webbsida: http://www.skolverket.se/

Englund, T. (2004). Deliberativa samtal i ljuset av deliberativ demokrati-en fråga om att utveckla deliberativa förhållningssätt. I R. Premfors \& K. Roth (Reds.), Deliberativ demokrati. Lund: Studentlitteratur.

Englund, T. (2006). Deliberative communication: a pragmatist proposal. Journal of Curriculum Studies, 38(5), 503-520.

Fritzell, C. (2003). Pedagogisk praktik som demokratiska samtal : några steg mot en praktiskpedagogisk deliberationsmodell. Växjö: Växjö univ.

Fritzén, L. (2003). Ämneskunnande och demokratisk kompetens-en integrerad helhet? Utbildning och demokrati, 12(3), 67-88.

Gerrevall, P. (2003). Bedömning av demokratisk kompetens - en pedagogisk utmaning. Utbildning och demokrati, 12(3), 41-66.

Gallie, W. B. (1955). Essentially contested concepts. Proceedings of the aristotelian society, 167-198.

Gutmann, A. \& Thompson, D. F. (1996). Democracy and disagreement : why moral conflict cannot be avoided in politics, and what should be done about it, Cambridge, Mass.: Belknap Press.

Habermas, J. (1978). Knowledge and human interests, London: Heinemann.

Jones, A. (2005). Talking cure: The Desire for Dialogue. I M. Boler, (Red.) Democratic Dialogue in education - Troubling speech, disturbing silence. New York: Peter Lang Publishing Inc.

Kolstø, S. D. (2000). Consensus projects: teaching science for citizenships. International Journal of Science Education, 22(6), 654-664.

Kolstø, S. D. (2001). Science Education for Citizenship. Thoughtful Decision-Making About Science-Related Social Issues. Faculty of Mathematics and Natural Science. Oslo: University of Oslo.

Kolstø, S. D. (2006). Et allmenndannende naturfag. Fagets betydning for demokratisk deltakelse. NorDiNa, 5, 82-99.

Latour, B. (1987). Science in action: how to follow scientists and engineers through society. Milton Keynes: Open University Press.

Liedman, S.-E. (1986). Kunskaper och kontroverser. I J. Naeslund, (Red.) Kunskap och begrepp : centrala motiv $i$ våra läroplaner. Stockholm: Liber Utbildningsförl.

Molloy, G. (2003). Det nödvändiga samtalet. Utbildning och demokrati, 12(2), 77-91. 
Osborne, J., Erduran, S. \& Simon, S. (2004). Enhancing the Quality of Argumentation in School Science. Journal of Research in Science Teaching, 41(10), 994-1020.

Paulsen, A. C. (2006). Naturfag i skolen i et kritisk demokratisk dannelseperspektiv. NorDiNa, 4, 69-84.

Ratcliffe, M. \& Grace, M. (2003). Science education for citizenship : teaching socio-scientific issues. Maidenhead: Open University Press.

Regeringen (1994). SKOLFS 1994:1. Förordning om läroplan för det obligatoriska skolväsendet, förskoleklassen och fritidshemmet (Lpo94).

Regeringen (1999). Det unga folkstyret. Demokratiutredningens forskarvolym, SOU 1999:93. J. Carle \& E. Amnå (Reds.). Stockholm: Fakta info direkt.

Ritchie, S. (2001). Actions and discourses for transformative understanding in a middle school science class. International Journal of Science Education, 23(3), 283-299.

Roth, K. (2003). Valfrihet, gemenskap och deliberativa samtal. I B. Jonsson \& K. Roth, (Reds.) Demokrati och lärande. Lund: Studentlitteratur.

Sadler, T. D. \& Donnelly, L. A. (2006). Socioscientific Argumentation: The effects of content knowledge and morality. International Journal of Science Education, 28(12), 1463-1489.

Skolverket (2000).Kursplaner och betygskriterier 2000. Stockholm: Fritzes.

Skolverket (2003). Värdegrundsboken. Om samtal för demokrati i skolan. Stockholm: Fritzes.

Solomon, J. (1991). Group Discussions in the classroom. School Science Review, 72, 29-34.

Sutton, C. (1992). Words, Science and Learning., Buckingham: Open University Press.

Säljö, R. (2000). Lärande i praktiken : ett sociokulturellt perspektiv. Stockholm: Prisma.

Tornberg, U. (2007). Vem äger språkundervisningens språk? I T. Englund red.), Utbildning som kommunikation. Deliberativa samtal som möjlighet.Göteborg: Daidalos.

Vygotskij, L. S. (1934/2005). Tänkande och språk. Göteborg: Daidalos. 